\title{
EFFECTS OF NATURAL WEATHERING ON SURFACE CHARACTERISTICS OF SCOTS PINE IMPREGNATED WITH WOLMANIT CX-8 AND VARNISHED
}

\author{
Caglar Altay ${ }^{1}$, Ergun Baysal ${ }^{2}$, Hilmi Toker ${ }^{2}$, Turkay Turkoglu 2 \\ Mustafa Kucuktuner ${ }^{3}$, Ahmet Gunduz ${ }^{2}$, Huseyin Peker 4 \\ 1Adnan Menderes University \\ Aydin, Turkey \\ 2Mugla Sitki Kocman University \\ Mugla, Turkey \\ ${ }^{3}$ Antalya Bilim University \\ Antalya, Turkey \\ ${ }^{4}$ Artvin Coruh University \\ Artvin, Turkey \\ (Received February 2019
}

\begin{abstract}
In this study, it was aimed to investigate the effects of weathering on some surface characteristics such as color and surface roughness changes of Scots pine impregnated with copper-containing chemical such as Wolmanit CX-8 (WCX-8) and varnished with synthetic varnish $(\mathrm{SV})$, cellulosic varnish $(\mathrm{CV})$, and polyurethane varnish $(\mathrm{PV})$ were investigated. Results showed that while the WCX-8 impregnated and PV coated Scots pine specimens showed better color stability than other treatment groups after weathering, only CV coated Scots pine gave the most negative effect on color stability. While, the untreated (control) wood surface turned from red to green and yellow to blue respectively, after weathering, other all treatment groups gave reddish and yellowish tone after weathering. Weathering conditions increased the surface roughness of control (untreated) and other all treatment groups. The control group gave a rougher surface than other treatment groups after weathering. Surface roughness increases were the lower for $\mathrm{CV}$ coated Scots pine wood than other treatment groups. The results showed that while WCX-8 impregnation before varnishing gave better color characteristics, generally it caused to increase the surface roughness of Scots pine after weathering.
\end{abstract}

KEYWORDS: Varnish, impregnation, color, surface roughness, natural weathering. 


\section{INTRODUCTION}

The wood material is a versatile natural resource in aesthetic, engineering, and structural applications. Because of its superior properties, wood material maintains its importance. Wood is used as a raw material in many areas (Ors and Keskin 2001, Bhat et al. 2010). Besides the positive properties of the wood material, there are also negative features. The wood is destructed by fungi and insects due to its natural structure and it is deformed due to the hygroscopic feature and changing its dimensions depending on the humidity and temperature of the atmosphere due to its hygroscopic feature. Therefore, the natural stability of wood materials cannot be long enough due to weaknesses such as resistance against different environmental factors during its service life (Usta 1993, Uysal 2005).

The wood material cannot withstand the effects of heat, light (UV, IR), humidity (rain, snow, humidity, and dew), mechanical effects (wind, sand, dirt) and biological pests (Budakci and Atar 2001, Kilic and Hafizoglu 2007, Williams 2005). Wood materials are usually exposed to solar radiation, water, wind, and dust during their useful life when used outdoor (Feist 1989). In outdoor climatic conditions, the effect of sun rays on the surface of the wood material changes the wood color very rapidly, and it causes a decrease in hardness, brightness, and mechanical properties. This is reported to be caused by wood extractives and chemical degradation of lignin (Feist 1989, Budakci 2006, Kilic and Hafizoglu 2007, Anderson et al. 1991, Sivrikaya et al. 2011). When exposed to outdoor conditions, smooth surface of wood material increases surface roughness due to lignin degradation and creates thin or deep cracks on the surface, washing with rainwater and color change by photodegradation (Feist 1989). Color is a basic visual feature for wood and wood-based products (Aydin and Colakoglu 2005). The color change is caused by the fact that the wood material absorbs all wavelengths of the electromagnetic radiation that initiates the photochemical reactions (Hon 1981).

There are many ways to protect wood products from outdoor degradation. One of these methods is to impregnate wood with various chemicals (Ozgenc et al. 2013). Photodegradation of wood can be limited by using some copper-containing chemicals (Jin et al. 1991, Cornfield et al. 1994, Zhang et al. 2009, Temiz et al. 2005, Ozgenc et al. 2012, Baysal et al. 2016, Ustun et al. 2016) treatment with inorganic salts particularly hexavalent chromium compounds (Feist 1979, Feist and Williams 1991, Evans et al. 1992, Yalinkilic et al. 1999, Baysal 2012). The most effective method of preventing the photodegradation of wood involves treating inorganic salts with dilute aqueous solutions, particularly hexavalent chromium compounds (Evans et al. 1992). Evans et al. (1992) and Kiguchi and Evans (1998) reported that the application of chromium trioxide to wood surfaces prevents lignin degradation during natural weathering. Williams et al. (1996) determined that the chromium oxides in copper-chromate-arsenic (CCA) which bond to the wood after treatment, decrease photodegradation of the wood surface. Sell and Feist (1985) reported that CCB-impregnated wood has high resistance and a protective effect against weathering. Feist and Ross (1995) and Jirouš-Rajković et al. (2004) determined that CCA provided long-term protection against weathering and erosion. However, it is no longer being produced for use in most residential settings, because it contains chromium and arsenic. Nowadays, some copper-containing wood preservatives such as Tanalith ${ }^{\circledR} \mathrm{E}(\mathrm{TN}-\mathrm{E})$ and Adolit-KD5 (AD-KD5) are being used in the forest products industry instead of CCA (Turkoglu et al. 2015a, Turkoglu et al. 2015b). The focus on copper-based preservatives has increased following concerns about the environmental effects of chromium and arsenic (Freeman et al. 2008). Therefore, the weathering aspects of treated wood with new preservatives become of practical importance (Temiz et al. 2007). Copper forms certain complexes with wood 
components, such as copper-cellulose complexes, copper-lignin complexes, and crystalline or amorphous inorganic/organic copper compounds, and reduces the degradation of the wood surface from weathering factors (Grelier et al. 2000, Temiz et al. 2005). The mechanism of action of copper-containing preservatives has been explained well in a study by Schmid et al. (2000).

Another method used to protect the wood surface against the UV effect is to cut the UV light and water contact with the wood surface by surface treatments (paints, varnishes, water repellent substances, etc.) (Ozgenc et al. 2013). Varnishes can provide wooden materials with the desired aesthetical properties like color and gloss (Meijer 2001). But, varnishing alone imparts to wood only superficial protection against some deteriorating agents for a limited time, often less than two years (Williams et al. 1996). Therefore, impregnation of wood with an appropriate water repellent or applying a varnish compatible preservative chemical prior to hazardous service conditions has been undertaken to make wood more stable against photochemical degradation, dimensional changes, biological decomposition, and fire (Wilkinson 1979, Williams et al. 1996, Yalinkilic et al. 1999). Moreover, the surface properties of wood materials can be improved easily by impregnating and finishing with various preservatives to provide different performance characteristics for individual applications, such as high hardness, impact resistance, suitable gloss, and chemical resistance (Chang and $\mathrm{Lu}$ 2012). Baysal et al. (2014) studied the effect of accelerated weathering on surface properties of Scots pine impregnated with Wolmanit-CB, TN-E, and $\mathrm{AD}-\mathrm{KD} 5$ and coated with synthetic varnish (SV) and polyurethane varnish (PV). According to the findings of their study, while weathering caused an increase in the hardness of impregnated and varnished specimens, the gloss of specimens decreased after weathering. Nzokou et al. (2011) determined that when the polyurethane varnish, which is water-repellent to the wood surface, is applied to the wood surface during impregnation operations, the color darkening caused by open weather is delayed and the increasing roughness on the wood surface is prevented. Yalinkilic et al. (1999) investigated the weathering performance of Scots pine and chestnut wood impregnated with chromium-copper-boron $(\mathrm{CCB})$ and applied with polyurethane varnish or alkyd-based synthetic varnish. They found that CCB impregnation greatly stabilized the surface color and reduced the mass loss of wood. It was also claimed that preservative treatment followed by a surface varnishing system protected the wood in long-term weathering conditions. Turkoglu et al. (2015a) investigated the color stability of the impregnated and varnished wood. They determined that the color stability of impregnated and varnished wood specimens gave better results than solely varnished wood specimens after natural weathering. In another study, Turkoglu et al. (2015b) studied some surface properties of wood impregnated with CCA, TN-E, AD-KD 5 and coated with polyurethane and synthetic varnishes after natural weathering. They found that after 6 months of natural weathering, the surface hardness and gloss loss of Scots pine and Oriental beech was the lowest in the TN-E impregnated and PV coated wood specimens.

In this study, some surface characteristics such as color and surface roughness changes of Scots pine impregnated with copper-containing chemical such as wolmanit CX-8 (WCX-8) and varnished Scots pine after 6 months of weathering were studied. Cellulosic, synthetic, and polyurethane varnishes were used as a coating material. Weathering was performed in Mugla, which is in the Southern Aegean Region of Turkey.

\section{MATERIALS AND METHODS}

\section{Preparation of wood specimens}

Scots pine wood specimens measuring $10 \times 100 \times 150 \mathrm{~mm}$ (radial by tangential by longitudinal) were prepared from air-dried sapwood of Scots pine (Pinus sylvestris L.) lumber. 
Wood surfaces were lightly sanded with 120 grit sandpaper, and then specimens were divided into three groups. The first group comprised non-impregnated and non-varnished (control) specimens. The second group comprised only varnished specimens. Finally, the third group consists of both impregnated and varnished samples. All specimens were conditioned at $20^{\circ} \mathrm{C}$ and $65 \%$ moisture content for three weeks before the impregnation procedure. According to technical data sheets of products, WCX-8 contains $2.8 \%$ bis-(n-cyclohexyldiazeniumdioxy)-copper (II) (copper (II)-HDO), 13.04\% basic copper (II) carbonate, 4\% boric acid and 2-amino ethanol (Wolmanit 2018).

\section{Impregnation process}

The Scots pine wood specimens were impregnated with the $5 \%$ aqueous solution of Wolmanit CX-8 (WCX-8), according to the ASTM D1413-07 (2007). All specimens were conditioned at $20^{\circ} \mathrm{C}$ and $65 \%$ moisture content for three weeks before tests. Ten replications were made for each treatment group. Retention values of chemicals were calculated using the following Eq. 1:

$$
\text { Retention }\left(\mathrm{kg}^{-3} \mathrm{~m}^{-3}\right)=[(\mathrm{G} \times \mathrm{C}) / \mathrm{V}] \times 10
$$

where: $G=\left(T_{2}-T_{1}\right)$ - treatment solution absorbed by the wood specimens $(g)$,

$\mathrm{T}_{1}$ - the weight of the wood specimens before impregnation $(\mathrm{g})$,

$\mathrm{T}_{2}$ - the weight of the wood specimens after impregnation $(\mathrm{g})$,

$\mathrm{C}$ - concentration (\%),

$\mathrm{V}$ - the volume of the wood specimen $\left(\mathrm{cm}^{3}\right)$.

\section{Varnishing process}

In this study, synthetic, polyurethane, and cellulosic varnishes were used to cover the wood material. The varnishes were applied to all surfaces and sides of the Scots pine specimens with a spray gun according to the ASTM D3023-98 standard (2003). Filler was used as the first varnishing applied to the wood surface was for filling the voids, and the second and third varnishing were applied for top varnishing. Sufficient time for layer settling was allowed between successive applications until the target retention of $100 \mathrm{~g} \cdot \mathrm{m}^{-2}$ for the primer and $100 \mathrm{~g} \cdot \mathrm{m}^{-2}$ for the top varnishing were reached, controlled by consecutive weighting. Specimens were left in ambient conditions for $24 \mathrm{~h}$ according to the manufacturer's recommendations after the first varnishing, and then surfaces were gently sanded using fine-grit sandpaper (220 grit) to obtain a smooth surface before the top varnishing. After the top varnishing of varnishes to the wood surfaces, test specimens were conditioned for three weeks.

\section{Color test}

The color parameters $L^{*}, a^{*}$, and $b^{*}$ were determined by the CIEL*a* $\mathrm{b}^{*}$ method. The $L^{*}$ axis represents the lightness, whereas $a^{*}$ and $b^{*}$ are the chromaticity coordinates. The $+a^{*}$ and $-a^{*}$ parameters represent the colors red and green, respectively. The $+b^{*}$ parameter represents yellow, whereas $-b^{*}$ represents blue. The $L^{*}$ value can vary from 100 (white) to zero (black) (Schmid et al. 2000). The colors of the specimens were measured by a colorimeter (X-Rite SP Series Spectrophotometer, X-ride Pantone, MI, USA) before and after weathering. The color difference, $\left(\Delta E^{*}\right)$ was determined for Scots pine wood according to ASTM-D 2244-14 (2016). The measured values are called the CIELab value. The color changes were determined using Eqs. 2 to 5: 


$$
\begin{aligned}
& \Delta a^{*}=a_{f}{ }^{*}-a_{i}^{*} \\
& \Delta b^{*}=b_{f}^{*}-b_{i}^{*} \\
& \Delta L^{*}=L_{f}^{*}-L_{i}^{*} \\
& \left(\Delta E^{*}\right)=\left[\left(\Delta a^{*}\right)^{2}+\left(\Delta b^{*}\right)^{2}+\left(\Delta L^{*}\right)^{2}\right]^{1 / 2}
\end{aligned}
$$

where: $\Delta a^{*}, \Delta b^{*}$, and $\Delta L^{*}$ represent the changes between the initial and final interval values.

\section{Surface roughness test}

In the study, Mitutoyo Surftest SJ-301 model surface roughness tester was used to measure surface roughness. This instrument was used for the surface roughness measurements according to DIN 4768 (1990). Three surface roughness parameters were studied for surface roughness measurement of Scots pine such as mean arithmetic deviation of the profile $(\mathrm{Ra})$, mean peakto-valley height (Rz), and root mean square (Rq) (Hiziroglu 1996, Hiziroglu and Graham 1998). The $\mathrm{Ra}$ is the average distance from the profile to the mean line over the length of assessment. The parameter $\mathrm{Rz}$ can be calculated from the peakto-valley values of five equal lengths within the profile, and $\mathrm{Rq}$ is the square root of the arithmetic mean of the squares of profile deviations from the mean line (Mummery 1993).

\section{Weathering test}

Each group consisted of 10 individual wood specimens. In total, 7 groups of wood specimens for each species were exposed to natural weathering in April to October for 6 months in the Mugla region in 2017. Wood panels were prepared for weathering exposure according to ASTM D 358-55 (2017).

Tab. 1: The details of the climate condition of Mugla city for 6 months.

\begin{tabular}{|l|c|c|c|c|c|c|c|}
\hline \multicolumn{1}{|c|}{ Months (2017) } & April & May & June & July & August & September & October \\
\hline Average temperature $\left({ }^{\circ} \mathrm{C}\right)$ & 13.0 & 17.6 & 23.9 & 28.6 & 26.1 & 23.0 & 15.8 \\
\hline Highest temperature $\left({ }^{\circ} \mathrm{C}\right)$ & 28.0 & 33.3 & 40.5 & 41.7 & 38.1 & 37.5 & 27.7 \\
\hline Lowest temperature $\left({ }^{\circ} \mathrm{C}\right)$ & 2.2 & 6.5 & 12.6 & 16.8 & 17.0 & 11.6 & 4.7 \\
\hline Humidity $(\%)$ & 63.5 & 61.0 & 49.3 & 36.6 & 51.4 & 45.2 & 59.7 \\
\hline Average wind speed $(\mathrm{m} / \mathrm{sn})$ & 1.6 & 1.5 & 1.7 & 1.8 & 1.6 & 1.5 & 14 \\
\hline $\begin{array}{l}\text { Total rainfall per month } \\
\left(\mathrm{mm}=\mathrm{kg} \cdot \mathrm{m}^{-2}\right)\end{array}$ & 62.9 & 42.3 & 8.8 & 0.4 & 112.1 & 1.6 & 103.2 \\
\hline Number of rainy days & 10 & 13 & 4 & 1 & 9 & 1 & 9 \\
\hline
\end{tabular}

A test site was established close to the Regional Meteorological Observation Station of Mugla which is in the Southern Aegean Region of Turkey to enable practical assessments. The details of the climate condition of Mugla city in this period are given in Tab. 1.

\section{RESULT AND DISCUSSION}

\section{Color Changes}

Tab. 2 shows $L^{*}, a^{*}$, and $b^{*}$ values of untreated (control), solely varnished, and impregnated and varnished Scots pine specimens before and after weathering and also illustrates the values of change for all three color parameters $\left(\Delta L^{*}, \Delta a^{*}\right.$, and $\left.\Delta b^{*}\right)$, as well as the total color changes $\left(\Delta E^{*}\right)$ of the wood specimens after 6 months of weathering. The retention value of the Scots pine 
wood specimens was found to be $35.91 \mathrm{~kg} \cdot \mathrm{m}^{-3}$ for impregnated with WCX-8. Before natural weathering, all of the treatment groups were showed a decrease in $\mathrm{L}^{*}$ values compared to the untreated (control) group. While the $L^{*}$ value of the control group was 75.16 , it was changed from 61.92 to 67.18 for the only varnished Scots pine. $L^{*}$ values of impregnated and varnished Scots pine wood specimens were changed from 36.38 to 41.21 . Moreover, $L^{*}$ values of the only varnished Scots pine was higher than WCX-8 impregnated and varnished Scots pine before weathering.

Tab. 2: The color changes of Scots pine specimens before and after natural weathering.

\begin{tabular}{|c|c|c|c|c|c|c|c|c|c|c|c|c|c|c|c|c|c|}
\hline & \multirow{3}{*}{$\begin{array}{c}\text { Retention } \\
\left(\mathrm{kg}^{\left.-\mathrm{m}^{-3}\right)}\right.\end{array}$} & \multicolumn{6}{|c|}{ Before natural weathering } & \multicolumn{6}{|c|}{ After natural weathering } & \multirow{2}{*}{\multicolumn{4}{|c|}{ After natural weathering }} \\
\hline & & \multicolumn{2}{|c|}{$L_{i}{ }^{*}$} & \multicolumn{2}{|c|}{$a_{i}{ }^{*}$} & \multicolumn{2}{|c|}{$b_{i}^{*}$} & \multicolumn{2}{|c|}{$L_{f}{ }^{*}$} & \multicolumn{2}{|c|}{$a_{f}{ }^{*}$} & \multicolumn{2}{|c|}{$b_{f}{ }^{*}$} & & & & \\
\hline & & Mean & SD & Mean & SD & Mean & SD & Mean & SD & Mean & SD & Mean & SD & $\Delta L^{*}$ & $\Delta a^{*}$ & $\Delta b^{*}$ & $\Delta E^{*}$ \\
\hline Control & - & 75.16 & 2.46 & 6.32 & 1.09 & 32.76 & 2.65 & 55.81 & 2.34 & 3.14 & 0.64 & 17.45 & 3.90 & -19.35 & -3.18 & -15.31 & 24.87 \\
\hline SV & - & 64.55 & 3.67 & 8.74 & 1.49 & 45.72 & 0.69 & 51.99 & 4.60 & 11.59 & 0.39 & 49.65 & 4.79 & -12.56 & 2.85 & 3.93 & 13.46 \\
\hline PV & - & 61.92 & 3.94 & 7.96 & 1.06 & 41.58 & 0.82 & 53.98 & 3.95 & 8.93 & 0.57 & 44.18 & 2.98 & -7.94 & 0.97 & 2.60 & 8.41 \\
\hline $\mathrm{CV}$ & - & 67.18 & 4.93 & 8.85 & 1.65 & 36.01 & 2.19 & 50.85 & 5.15 & 11.98 & 0.35 & 46.67 & 4.45 & -16.33 & 3.13 & 10.66 & 19.75 \\
\hline WCX-8+ SV & 35.91 & 38.05 & 4.86 & 3.46 & 1.00 & 37.35 & 5.93 & 36.84 & 4.02 & 9.10 & 0.51 & 39.05 & 5.36 & \begin{tabular}{|l|}
-1.21 \\
\end{tabular} & 5.64 & 1.70 & 6.01 \\
\hline WCX-8+ PV & 35.91 & 36.38 & 2.60 & 1.22 & 0.76 & \begin{tabular}{|l|}
29.86 \\
\end{tabular} & 2.82 & \begin{tabular}{|l|}
36.21 \\
\end{tabular} & 2.24 & 6.40 & 0.61 & 30.86 & 2.41 & -0.17 & 5.18 & 1.00 & 5.27 \\
\hline $\begin{array}{l}\text { WCX-8+ } \\
\mathrm{CV}\end{array}$ & 35.91 & \begin{tabular}{|l|}
41.21 \\
\end{tabular} & 2.12 & 0.93 & 0.49 & 29.05 & 2.32 & 38.24 & 2.65 & 8.93 & 0.29 & 38.50 & 2.05 & -2.97 & 8.00 & 9.45 & 12.73 \\
\hline
\end{tabular}

Note: Ten replicates were made for each treatment group. SD: Standard deviation.

The decrease in the $L^{*}$ value of Scots pine wood specimens showed that the specimens became darker after the WCX-8 treatment. These results are in good agreement with that of Baysal (2012), Ustun et al. (2016), and Simsek and Baysal (2012) which studied the effects of some impregnation chemicals on color changes of wood. According to our results, $a^{*}$ and $b^{*}$ values of untreated (control) were 6.32 and 32.76 before weathering. While $a^{*}$ values changed from 7.96 to $8.85, b^{*}$ values changed from 36.01 to 45.72 for the only varnished Scots pine before weathering. Our results showed that $a^{*}$ and $b^{*}$ values of the only varnished Scots pine was higher than the untreated (control) group before weathering. Impregnation with WCX-8 before varnishing caused to decrease $a^{*}$ and $b^{*}$ values of Scots pine. Baysal et al. (2014) studied color changes of Scots pine specimens impregnated with copper-chromate-boron, Tanalith ${ }^{\circledR} \mathrm{E}$, and Adolit KD-5 and coated with cellulosic and polyurethane varnishes. They reported that $\mathrm{a}^{*}$ and $\mathrm{b}^{*}$ values of the only varnished Scots pine was higher than impregnated and varnished Scots pine. Our results are compatible with data Baysal et al. (2014).

After 6 months of weathering, the negative lightness stability $\left(\Delta \mathrm{L}^{*}\right)$ values for untreated (control) and other all treated Scots pine specimens were occurred after weathering. Therefore, the wood surface became rougher and darker after weathering. The darkening of Scots pine might be have been due to the degradation of lignin and other non-cellulosic polysaccharides (Hon and Chang 1985, Grelier et al. 2000, Petric et al. 2004). WCX-8-impregnated and varnished Scots pine caused less change in the lightness than the only varnished Scots pine specimens in this study. It may be due to the fact that the WCX-8 impregnation developed the stabilization of wood color in the visible region through a reduction in the lignin degradation that resulted from UV light (Grelier et al. 2000). After 6 months of weathering, $\Delta a^{*}$ and $\Delta b^{*}$ values of control were found to be as -3.18 and -15.31 , respectively. The negative $\Delta a^{*}$ and $\Delta b^{*}$ values showed that the wood surface turned from red to green and yellow to blue respectively, after weathering. Varnished and impregnated and the only varnished Scots pine wood surfaces gave positive $\Delta a^{*}$ and $\Delta b^{*}$ values after weathering. Positive $\Delta a^{*}$ and $\Delta b^{*}$ values show that wood specimen surface maintained reddish and yellowish tone after weathering. It was determined that except for untreated (control group), the $\Delta \mathrm{a}^{*}$ and $\Delta \mathrm{b}^{*}$ values of other all treatment groups showed positive values after weathering. As a result, except 
for untreated (control), all of the treatment groups tended to reddish and yellowish respectively, after weathering. While total color change $\left(\Delta \mathrm{E}^{*}\right)$ was 24.87 for untreated (control), it was changed from 5.27 to 19.75 for all treatment groups after weathering. Color change values showed that the best color stability was observed with WCX-8 impregnated and PV coated Scots pine after weathering. The reduction in $\Delta \mathrm{E}^{*}$ of pre-impregnated and PV-coated Scots pine suggested a positive contribution to color stability in previous studies (Yalinkilic et al. 1999, Baysal 2008). The marked improvement in the performance of polyurethane varnishes on copper-chromatetreated surfaces was reported in a previous study (Black and Mraz 1974). Specimens impregnated with $\mathrm{CCB}+\mathrm{PV}$ showed remarkable changes in lignin after weathering, but changes were distinctly different from those in untreated specimens (Yalinkilic et al. 1999). WCX-8 impregnation before varnishing reduced total color changes after weathering. It might be due to the photostabilization of wood via copper treatments that might be explained by retardation of the carbonyl group formation and reduced delignification after weathering (Temiz et al. 2005). These findings are compatible with the literature reporting that copper-containing treatments provided better protection for color changes than untreated wood specimens (Ozgenc and Yildiz 2014, Grelier et al. 2000, Temiz et al. 2005). Baysal et al. (2016) studied the color stability of bamboo wood impregnated with some copper-containing chemicals after accelerated weathering. They found that the best preservative for bamboo found to be $\mathrm{CCB}$ against color changes after accelerated weathering. The chromium and copper in the CCB formulation might create a synergistic effect to retard the surface degradation during weathering. Temiz et al. (2005), Ozgenc and Yildiz (2014) found that the best color stability was Tanalith ${ }^{\circledR} \mathrm{E}$ with polyurethane varnishing for both Oriental beech and Scots pine wood specimens. Tanalith ${ }^{\circledR}$ E treatment both slowed down photodegradation by retarding the formation of carbonyl groups. The light resistance of Tanalith ${ }^{\circledR} \mathrm{E}$ treated wood likely results from $\mathrm{Cu}$ (II) chelating with functional groups in wood. These chelates can photostabilize wood and retard the formation of carbonyl groups. Our results are in good agreement with these researchers' findings.

\section{Surface roughness changes}

The importance of surface roughness, as a significant parameter for determination of the surface quality of wood products, is well recognized, and the surface quality of wood is affected by many factors (Yildiz et al. 2013). Surface roughness parameters, such as $\mathrm{Ra}, \mathrm{Rz}$, and $\mathrm{Rq}$ values of Scots pine wood before and after weathering are given in Tab.3.

Tab. 3: The surface roughness values of Scot spine specimens before and after natural weathering.

\begin{tabular}{|c|c|c|c|c|c|c|c|c|c|c|c|c|c|c|c|}
\hline & \multicolumn{6}{|c|}{ Before natural weathering } & \multicolumn{6}{|c|}{ After natural weathering } & \multicolumn{3}{|c|}{$\begin{array}{c}\text { Differences } \\
(\%)\end{array}$} \\
\hline & \multicolumn{2}{|c|}{$\mathbf{R a}$} & \multicolumn{2}{|c|}{$\mathbf{R z}$} & \multicolumn{2}{|c|}{$\mathbf{R q}$} & \multicolumn{2}{|c|}{$\mathbf{R a}$} & \multicolumn{2}{|c|}{$\mathrm{Rz}$} & \multicolumn{2}{|c|}{$\mathbf{R q}$} & \multirow{2}{*}{$\mathbf{R a}$} & \multirow{2}{*}{$\mathbf{R z}$} & \multirow{2}{*}{$\mathbf{R q}$} \\
\hline & Mean & $\mathrm{SD}$ & Mean & SD & Mean & SD & Mean & $\mathrm{SD}$ & Mean & $\mathrm{SD}$ & Mean & SD & & & \\
\hline Control & 1.28 & 0.76 & 7.08 & 2.23 & 1.41 & 0.44 & 3.00 & 1.23 & 17.27 & 4.88 & 3.68 & 1.50 & 135 & 144 & 161 \\
\hline SV & 0.27 & 0.14 & 1.22 & 0.58 & 0.32 & 0.10 & 0.47 & 0.21 & 2.20 & 1.21 & 0.68 & 0.31 & 77 & 81 & 113 \\
\hline $\mathrm{PV}$ & 0.07 & 0.03 & 0.69 & 0.15 & 0.12 & 0.06 & 0.12 & 0.04 & 1.46 & 0.38 & 0.24 & 0.04 & 85 & 112 & 104 \\
\hline $\mathrm{CV}$ & 0.32 & 0.11 & 3.13 & 0.49 & 0.51 & 0.13 & 0.42 & 0.11 & 4.00 & 0.85 & 0.67 & 0.37 & 34 & 28 & 33 \\
\hline WCX-8+SV & 0.16 & 0.08 & 1.27 & 0.23 & 0.21 & 0.11 & 0.35 & 0.08 & 2.30 & 0.66 & 0.49 & 0.09 & 121 & 76 & 135 \\
\hline WCX-8+ PV & 0.04 & 0.01 & 0.52 & 0.21 & 0.06 & 0.02 & 0.08 & 0.04 & 1.16 & 0.37 & 0.14 & 0.06 & 107 & 124 & 148 \\
\hline $\mathrm{WCX}-8+\mathrm{CV}$ & 0.32 & 0.11 & 3.11 & 0.72 & 0.52 & 0.14 & 0.57 & 0.15 & 3.60 & 0.92 & 0.81 & 0.31 & 81 & 16 & 57 \\
\hline
\end{tabular}

Note: Ten replicates were made for each treatment group. SD: Standard deviation. 
The untreated (control) specimen had an average $\mathrm{Ra}, \mathrm{Rz}$, and $\mathrm{Rq}$ values of $1.28,7.08$, and 1.41, respectively, before weathering. Results showed that the surface roughness values of the untreated (control) group were higher than the other all treatment groups before the weathering. The wooden materials with rough surface require much more sanding process compared to one with a smooth surface, which leads to decrease in thickness of the material and, therefore, increases the losses due to the sanding process (Dundar et al. 2008). However, the roughness of wood is a complex phenomenon. Several factors such as the anatomical structure of wood, growing characteristics, machining properties and pre-treatments of wood before machining should be considered for the evaluation of the surface roughness of wood (Aydin and Colakoglu 2003, Aydin and Colakoglu 2005, Temiz et al. 2005).

Weathering caused to increase the surface roughness of un-treated (control) and other all treatment groups. Except for the untreated (control) group, surface roughness increases were the highest WCX-8 impregnated and PV coated Scots pine wood after weathering. Our results showed that surface roughness increases were the lowest for only CV coated Scots pine after weathering. The increase of $\mathrm{Ra}, \mathrm{Rz}$, and $\mathrm{Rq}$ were $34 \%, 28 \%$, and $33 \%$ respectively, for $\mathrm{CV}$ coated Scots pine after weathering. This increase in smoothness is very important for many applications of solid wood. In addition, losses occurring in the planning machine are reduced and high-quality surfaces are attained (Unsal and Ayrilmis 2005). Kerberet et al. (2016) determined that in addition to the leaching of lignin degraded by natural weathering reactions, the increase in the roughness of the wood is also related to sudden changes of humidity (absorption and desorption of the humidity) causing the presence of superficial cracks. Turkulin (2017) reported that light irradiation mostly degraded the middle lamella, which is between two cell walls and holds the cells together. This degradation increases the surface roughness of the wood (Tolvaj et al. 2014). The increase in $\mathrm{Ra}, \mathrm{Rz}$, and $\mathrm{Rq}$ values were $135 \%, 144 \%$, and $161 \%$, respectively for the control group after natural weathering. The surface roughness of the untreated (control) group was higher than the only varnished Scots pine after weathering. In varnishes, cellulosic varnish gave the best results in terms of surface roughness of Scots pine after weathering. Except for Rz values of WCX-8 impregnated and then CV and SV coated Scots pine, WCX-8 impregnation before varnishing caused to increase the surface roughness of Scots pine after weathering compared to the only varnished Scots pine after weathering. Ozgenc and Yildiz (2014) investigated the surface roughness of some wood species impregnated with some coppercontaining chemicals. They found that surface roughness values of impregnated wood species were lower than un-impregnated wood species during the weathering time. In impregnation chemicals, except for didecyldimethylammonium chloride (DDAC), other treatment groups decreased surface roughness of wood specimens after artificial weathering. Temiz et al. (2005) found that the surface roughness values of CCA-impregnated Scots pine were lower than that of un-treated Scots pine after accelerated weathering. Our results are compatible with these researchers' findings.

\section{CONCLUCIONS}

This study was performed to determine some physical characteristics such as color and surface roughness changes of Scots pine WCX-8 impregnated and varnished Scots pine after weathering. The lightness value of untreated (control) group was higher than the other treatment groups before the weathering. WCX-8 treatment before varnishing caused lightness loss of Scots pine before weathering. The negative lightness stability $\left(\Delta \mathrm{L}^{*}\right)$ values for untreated (control) and other all treatments were occurred after weathering. Moreover, except for untreated (control) group, varnished and impregnated and varnished Scots pine wood surfaces gave positive 
$\Delta a^{*}$ and $\Delta b^{*}$ values after weathering, So, Scots pine wood surfaces indicate to become reddish and yellowish. The total color change $\left(\Delta \mathrm{E}^{*}\right)$ values of the only varnished and impregnated and varnished Scots pine wood specimens were less than that of an untreated (control) specimen. Our results showed that the best color stability was obtained with WCX-8 impregnated and PV coated Scots pine after weathering. Untreated (control) and impregnated and varnished Scots pine wood surfaces were softened after weathering. The surface roughness increases of the treated Scots pine were lower than that of un-treated (control) Scots pine after weathering. In general, WCX-8 treatment before varnishing increased the surface roughness of Scots pine after weathering. The surface roughness increases were the lowest with CV coated Scots pine after weathering.

In conclusion, WCX-8 impregnation before varnishing was more effective in stabilizing the wood color. However, generally, it gave rougher wood surfaces with varnish than the only varnished wood surfaces after weathering.

\section{REFERENCES}

1. Anderson, E.L., Pawlak, Z., Owen, N.L., Feist, W.C., 1991: Infrared studies of wood weathering. Society for Applied Spectroscopy 45 (4): 641- 647.

2. ASTM-D 358-55, 1970: Standard specification for wood to be used panels in weathering tests of paints and varnishes.

3. ASTM-D, 3023-98, 2003: Standard practice for determination of resistance of factoryapplied coatings on wood products to stains and reagents.

4. ASTM-D, 1413-07, 2007: Standard test method for wood preservatives by laboratory soilblock cultures.

5. ASTM-D, 2244-16, 2016: Standard practice for calculation of color tolerances and color differences from instrumentally measured color coordinates.

6. Aydin, I., Colakoglu, G., 2003: Roughness on wood surfaces and roughness measurement methods. Artvin Coruh University Journal of Forestry Faculty 4(1-2): 92-102.

7. Aydin, I., Colakoglu, G., 2005: Effects of surface inactivation, high temperature drying and preservative treatment on surface roughness and colour of alder and beech wood. Applied Surface Science 252 (2): 430-440.

8. Baysal, E., 2008: Some physical properties of varnish coated wood preimpregnated with copper-chromated boron (CCB) after 3 months of weathering exposure in Southern Eagen Sea region. Wood Research 53(1): 43-54.

9. Baysal, E., 2012: Surface characteristics of CCA treated Scots pine after accelerated weathering. Wood Research 57(3): 375-382.

10. Baysal, E., Tomak, E.D., Ozbey, M., Altin, E., 2014: Surface properties of impregnated and varnished Scots pine wood after accelerated weathering. Coloration Technology 130(2): 140-146.

11. Baysal, E., Tomak, E. D., Topaloglu, E., Pesman, E., 2016: Surface properties of bamboo and Scots pine impregnated with boron and copper based wood preservatives after accelerated weathering. Maderas. Ciencia y Tecnología 18(2): 253-264.

12. Bhat, I.H., Khalil, H.P.S., Awang, K.B., Bakare, I.O., Issam, A.M., 2010: Effect of weathering on physical, mechanical and morphological properties of chemically modified wood materials. Materials and Design 31(9): 4363-4368.

13. Black, J.M., Mraz, E.A., 1974: Inorganic surface treatments for weather-resistant natural finishes. In: Forest Products Laboratory Lab Madison Wis, Forest Service, U.S. Department of Agriculture. Washington, Pp. 1-41. 
14. Budakci M., Atar M., 2001: Effects of bleaching process on hardness and glossiness of pine wood (Pinus sylvestris L.) exposed to outdoor conditions. Turkish Journal of Agriculture and Forestry 25: 201-207.

15. Budakci, M., 2006: Effect of outdoor exposure and bleaching on surface color and chemical structure of scots pine. Progress in Organic Coatings 56 (1): 46-52.

16. Chang, C.W., Lu, K.T., 2012: Natural castor oil based 2-package waterborne polyurethane wood coatings. Progress in Organic Coatings 75(4): 435-443.

17. Cornfield, J.A., Hale, M., Fettis, G., 1994: A comparison of analytical and visual techniques used for assessment of weathering properties of chromium and copper azole treated timber. In: International Resarch Group on Wood Preservation, IRG/WP/20023.

18. DIN 4768, 1990: Determination of values of surface roughness parameters $\mathrm{Ra}, \mathrm{Rz}, \mathrm{Rmax}$ using electrical contact (stylus) instruments, concepts and measuring conditions.

19. Dundar T., As N., Korkut, S., Unsal, O., 2008: The effect of boiling time on the surface roughness of rotary-cut veneers from oriental beech (Fagus orientalis L.). Journal of Materials Processing Technology 199(1-3): 119-123.

20. Evans, P.D., Michell, A.J., Schmalzl, K.J., 1992: Studies of the degradation and protection of wood surfaces. Wood Science and Technology 26(2): 151-163.

21. Feist, W.C., 1979: Protection of wood surfaces with chromium trioxide. Research Paper. FPL 339, Forest Products Laboratory, Madison, WI, Pp. 1-11.

22. Feist, W.C., 1989: Outdoor wood weathering and protection, 225. Series, United States of America. American Chemical Society, Pp. 263-298.

23. Feist, W.C., Williams, R.S., 1991: Weathering durability of chromium-treated Southern pine. Forest Products Journal 41(1): 8-14.

24. Feist, W.C., Ross, A.S., 1995: Performance and durability of finishes on previously coated CCA-treated wood. Forest Products Journal 45(9): 29-36.

25. Freeman, M.H., Mcintyre, C.R., 2008: A comprehensive review of copper-based wood preservatives with a focus on new micronized or dispersed copper systems. Forest Products Journal 58(11): 6-27.

26. Grelier, S., Castellan, A., Kamdem, D.P., 2000: Photo-protection of copper amine treated wood. Wood and Fiber Science 32(2): 196-202.

27. Hiziroglu, S., 1996: Surface roughness analysis of wood composites: a stylus method. Forest Products Journal 46 (7/8): 67-72.

28. Hiziroglu, S., Graham, S., 1998: Effect of press closing time and target thickness on surface rougness of particle board. Forest Products Journal 48: 50-54.

29. Hon, D.N.S., 1981: Photochemical degradation of lignocellulosic material. In: Developments in polymer degradations, N. Grassie, ed., Appl. Sci. Publ., London. Pp. 229-281.

30. Hon, D.N.S., Chang, S.T., 1985: Photoprotection of wood surfaces by wood-ion complexes. Wood and Fiber Science 17(1): 92-100.

31. Jin, L., Archer, K., Preston, A., 1991: Surface characteristics of wood treated with various AACs, ACQ and CCA formulations after weathering. In: International Research Group on Wood Preservation Conference. Kyoto, Japan IRG/WP/2369. Pp. 229-281.

32. Jirous-Rajkovic, V., Bogner, A., Radovan, D., 2004: The efficiency of various treatments in protecting wood surfaces against weathering. Surface Coatings International Part B: Coatings Transactions 87(1): 15-19.

33. Kerber, P. R., Stangerlin, D. M., Pariz, E., Melo, R.R., Souza, A.P., Leandro, C., 2016: Colorimetry and surface roughness of three amazonian woods submitted to natural weathering. Nativa 4 (5): 303-307. 
34. Kiguchi, M., Evans, P.D., 1998: Photostabilization of wood surface using a grafted benzophenone UV absorber. Polymer Degradation Stability 61(1): 33-45.

35. Kilic, A., Hafizoglu, H., 2007: Influences of weathering on chemical structure of wood and protection treatments. Süleyman Demirel University Journal of Forestry Faculty 2: 175-183.

36. Meijer, M.D., 2001: Review on the durability of exterior wood coatings with reduced VOCcontent. Progress in Organic Coatings 43(4): 217-225.

37. Mummery, L., 1993: Surface texture analysis. The Handbook. Hommelwerke, Muhlhausen, Germany, 106 pp.

38. Nzokou, P, Kamdem, D. P., Temiz, A., 2011: Effect of accelerated weathering on discoloration and roughness of finished ash wood surfaces in comparison with red oak and hard maple. Progress in Organic Coatings 71(4): 350-354.

39. Ors, Y., Keskin, H., 2001: Ağaç Malzeme Bilgisi, 1. ed, Ankara, Turkey. Nobel Publisher, $183 \mathrm{pp}$.

40. Ozgenc, O., Hiziroglu, S., Yildiz, U.C. 2012: Weathering properties of wood species treated with different coating applications. BioResources 7(4): 4875-4888.

41. Ozgenc, O., Yildiz, U.C, Yildiz, S., 2013: The wood surface protection with some new generation wood preservatives and coating processings against weathering conditions. Artvin Coruh University. Journal of Forestry Faculty 14 (2): 203-215.

42. Ozgenc, O., Yildiz, U.C., 2014: Surface characteristics of wood treated with new generation preservatives after artificial weathering. Wood Research 59(4): 605-616.

43. Petric, M., Kricej, B., Humar, M., Pavlic, M., Tomazic, M., 2004: Patination of cherry wood and spruce wood with ethanolamine and surface finishes. Surface Coatings International Part B: Coatings Transactions 87(3): 195-201.

44. Schmid, S., Webster, R. D., Evans, P. D., 2000: The use of ESR spectroscopy to assess the photostabilising effects of wood preservatives. In: International Research Group on Wood Preservation Conference. Hawaii, USA IRG/WP 00-20186, 2000. Pp. 1-9.

45. Sell, J., Feist, W.C., 1985: Weathering behavior of chromium-copper-boron treated wood. Holzals Roh- und Wekstoff 43(12): 518-523.

46. Simsek, H., Baysal, E., 2012: An investigation on colour and gloss changes of wood impregnated with borates. Wood Research 57(2): 271-277.

47. Sivrikaya H., Hafizoglu H., Yasav A., Aydemir D., 2011: Natural weathering of oak (Quercus petraea) and chestnut (Castanea sativa) coated with various finishes. Color Research and Application 36 (1): 72-78.

48. Temiz, A., Yildiz, U.C., Aydin, I., Eikenes, M., Alfredsen, G., Colakoglu, G., 2005: Surface roughness and colour characteristics of wood treated with preservatives after accelerated weathering test. Applied Surface Science 250(1-4): 35-42.

49. Temiz, A., Terziev, N., Eikenes, M., Hafren, J., 2007: Effect of accelerated weathering on surface chemistry of modified wood. Applied Surface Science 253(12): 5355-5362.

50. Tolvaj, L., Molnar, Z., Magoss, E., 2014: Measurement of photodegradation-caused roughness of wood using a new optical method. Journal of Photochemistry and Photobiology B: Biology 134: 23-26.

51. Turkoglu, T., Baysal, E., Toker, H., 2015a: The effects of natural weathering on color stability of impregnated and varnished wood materials. Advances in Materials Science and Engineering 1-9.

52. Turkoglu, T., Baysal, E., Toker, H., Ergün, M.E., 2015b: The effects of natural weathering on hardness and gloss of impregnated and varnished Scots pine and oriental beech wood. Wood Research 60(5): 833-844. 
53. Usta, I., 1993: The current situation and recommendations developing of impregnation wood industry in Turkey. M.Sc. Thesis. Hacettepe University, Ankara, Turkey. 135 pp.

54. Uysal, B., 2005: Wood material course notes. Karabük, Turkey. 65 pp.

55. Ustun, S., Baysal, E., Turkoglu, T., Toker, H., Sacli, C., Peker, H., 2016: Surface characteristics of Scots pine treated with chemicals containing some copper compounds after weathering. Wood Research 61(6): 903-914.

56. Unsal, O., Ayrilmis, N., 2005: Variations in compression strength and surface roughness of heat-treated Turkish riverredgum (Eucalyptus camaldulensis) wood. Journal of Wood Science 51(4): 405-409.

57. Wilkinson, J.G., 1979: Industrial Timber preservation. The Rentokil Library. Associated Business Press, London. 532 pp.

58. Williams, R.S., Knaebe, M.T., Feist, W.C., 1996: Finishes for exterior wood: Selection, application, and maintenance. Forest Products Society, USDA Forest Service, $127 \mathrm{pp}$.

59. Williams, R.S., 2005: Handbook of Wood Chemistry and Wood Composites. Weathering of wood. Forest Products Laboratory. Madison, USA. 733 pp.

60. Yalinkilic, M.K., Ilhan, R., Imamura, Y., Takahashi, M., Demirci, Z., Yalinkilic, A.C., 1999: Weathering durability of CCB-impregnated wood for clear varnish coatings. Journal of Wood Science 45(6): 502-514.

61. Yildiz, S., Tomak, E.D., Yildiz, U.C., Ustaomer, D., 2013: Effect of artificial weathering on the properties of heat treated wood. Polymer Degradation and Stability 98(8): 1419-1427.

62. Zhang, J., Kamdem, P.D., Temiz, A., 2009: Weathering of copper-amine treated wood, Applied Surface Science 256 (3): 842-846.

\author{
Caglar Altay \\ Adnan Menderes University \\ Aydin Vocational School \\ Department of Furniture and Decoration \\ ogOoo Aydin \\ TurkeY \\ Ergun Baysal*, Hilmi Toker \\ Mugla Sitki Kocman University \\ Faculty of Technology \\ Department of Wood Science and Technology \\ 48000 Mugla \\ TuRKeY \\ *Corresponding author: ergun69@yahoo.com
}

Turkay Turkoglu

Mugla Sitki Kocman University

Koycegiz Vocational School

Department of Forestry

48800 Mugla

Turkey 


\author{
Mustafa Kucuktuvek \\ Antalya Bilim University \\ Faculty of Fine Arts and Architecture \\ Department of Interior Architecture and Environmental Design \\ o7igo Antalya \\ TURKEY \\ Ahmet Gunduz \\ Mugla Sitki Kocman University \\ Faculty of Technology \\ Department of Wood Science and Technology \\ 48000 Mugla \\ TURKEY \\ Huseyin Peker \\ Artvin Coruh University \\ Faculty of Forestry \\ Department of Forest Industry Engineerng \\ o80ooo Artvin \\ Turkey
}


